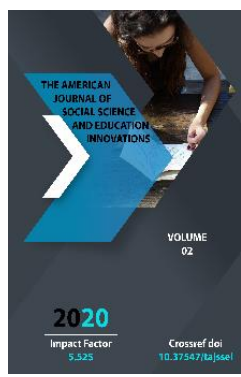

\title{
EU Freedom Of Establishment And The Theories Of Incorporation In The Context Of Free Movement Of MNEs
}

\author{
Yulduz Akhtamova \\ Lecturer At Tashkent State University Of Law, Uzbekistan
}

Copyright: Original content from this work may be used under the terms of the creative commons attributes 4.0 licence.

\section{ABSTRACT}

The creation of a single market with no internal borders where free mobility is guaranteed is one of the main goals of the European Union. Accordingly, along with certain fundamental freedoms, Treaty on the Functioning of the European Union (TFEU) provides the right of establishment for nationals as well as companies in a territory of another Member State. Accordingly, a decentralized nature of multinational enterprises (MNEs) involves various cross-border operations. The aim of this paper is to explore to what extent these transnational objectives of MNEs can be achieved under the freedom of establishment principle of EU law and incorporation theories of Member States. Firstly, it analyzes different scenarios of company mobility such as transfer of registered office or real seat and transnational mergers. Secondly, it examines the freedom of companies to choose legal forms of their cross-border establishment. Finally, it evaluates the most recent judgment in Polbud case in the light of decisions made in previous cases.

\section{KEYWORDS}

The freedom of establishment principle, incorporation theories, EU law, free movement of MNEs, transfer of registered office or real seat, transnational mergers.

\section{INTRODUCTION}

Freedom of establishment concerning corporate mobility is embodied in Articles 49 (Ex Art.43 TEC) and 54 (Ex Art.48 TEC) of the TFEU. In particular, Article 49 states that
'... restrictions on the freedom of establishment of nationals of a Member State in the territory of another Member State shall be prohibited. Such prohibition shall also apply 
to restrictions on the setting-up of agencies, branches or subsidiaries by nationals...' 1 while Article 54 provides that lawfully incorporated companies in a Member State shall be treated in the same way as nationals of Member States ${ }^{2}$. However, unlike natural persons who gain their nationality by default at birth, companies must comply with relevant national laws so as to acquire their legal identity (nationality) and qualify for crossborder establishment rights ${ }^{3}$. Thus, Article 54 makes companies subject to national company laws of Member States, which vary from State to State and impose different conditions on companies for gaining and retaining their nationality.

Since the incorporation of companies' means is regulated by Member States, they are free to decide on the connecting factor between companies and their national territory. ${ }^{4}$ Specifically, Member States are unrestricted to require the presence of a particular type of seat within their territories for the incorporation of the companies and determination of the applicable law. 5 There are two types of doctrines applied by Member States to deciding the connecting factor: the real seat theory and incorporation theory. States (nine Members) following the real seat theory require the existence of central administration while those (six Members) following the

\footnotetext{
${ }^{1}$ Consolidated Version of the Treaty on the Functioning of the European Union [2012] OJ C326/47

${ }^{2}$ Ibid

3 Aaron Khan 'Corporate Mobility, Market Access and the Internal Market' (2015) 40 (3) European Law Review pp.2 <https://www.westlaw.com/Document/I2BB262D0102A11 E5AD4AE24CFD3BB17D/View/FullText.html?transitionTyp e=Default\&contextData $=($ sc. Default) $\& V R=3.0 \& R S=c b l t 1$. 0> accessed 15 November 2019

${ }^{4}$ Case 81/87 Daily Mail and General Trust plc [1988] ECR 5483 para. 19
}

incorporation theory require the presence of registered office. ${ }^{6}$ Thus, when companies are involved in cross-border operations, these two conflicting theories may result in disputes with regard to the status of companies and applicable laws, thereby causing restrictions on free movement rights. In such cases, the burden of reconciling conflicting interests falls on the European Court of Justice (ECJ), which is supposed to decide the scope of freedom of establishment and define the "restrictions" made on it by national regulations. Therefore, it is essential to strike a right balance between national regulatory autonomy and free movement.

\section{Transfer of Registered Office or Real Seat}

Economic globalization and regional integration made it common for companies to locate their central administration or economic activities ("real seat") in a State which differs from the State of their registration/incorporation ("registered seat"). Under EU law, companies are entitled to transfer their registered office or real seat by the right of freedom of establishment. However, the transfer of particular type of company's seat is influenced by the role that the seat in question plays in international private law and national company law of the

\footnotetext{
${ }^{5}$ HrvojeMarkovinovic and AntunBilic 'The Tranfer of A Company Seat to a Different Member State in the Light of the Recent “POLBUD” Decision' (2018) 5 (2) Journal for International and European Law and Market Integrations pp.99 <http://dx.doi.org/10.22598/iele.2018.5.2.3>accessed 15 November 2019

6Jan Wouters 'Private International Law and Companies' Freedom of Establishment' European Business Organization Law Review (2001) 2 (1) pp. 132-135 <https://search.proquest.com/docview/38291987?accoun tid=14116 $>$ accessed 18 November
} 
home and host state. ${ }^{7}$ Specifically, company law of Member States may require liquidation of a company, which intends to transfer its real seat or registered office. In this case, question arises whether a company can invoke its right of establishment to carry out such transfers without loss of its nationality. This issue is addressed by the ECJ in Daily Mail, Cartesio and vale cases.

Daily Mail and General Trust (DMGT) was a company incorporated in the UK, which sought to transfer its central administration to Netherlands. ${ }^{8}$ According to UK company law, although connecting factor for incorporation was a registered office ${ }^{9}$, companies were evaluated for tax based on the place of their "central management and control"10. Accordingly, transfer of central management and control was allowed only with the consent of the Treasury. ${ }^{11}$ DMGT claimed that such a "consent" prerequisite was a restriction on its right of freedom of establishment. The ECJ decided that such transfer does not fall within the ambit of Art. 49 protection. ${ }^{12}$ It justified this decision by asserting that 'companies are creatures of national law and exist by virtue of the varying national legislation which determines their incorporation and functioning'. ${ }^{13}$ Moreover, it was clarified that due to the lack of harmonization of incorporation conditions, the issue concerning transfer of a real seat or registered office

\footnotetext{
${ }^{7}$ Markovinovic and Bilic (n 5) pp.99

${ }^{8}$ Case $81 / 87$ Daily Mail (n 4)

9 lbid

10 Income and Corporation Taxes Act 1970 s 487 (7) (now annulled)

${ }^{11}$ Ibid s 482 (1)

${ }^{12}$ Case $81 / 87$ Daily Mail (n 4)

13 Ibid para. 19

${ }^{14}$ Ibid paras.20-25

15 Case 210/06 CartesioOktatóésSzolgáltatóbt. [2008] ECR I-9641
}

without losing nationality is not resolved by the freedom of establishment. ${ }^{14}$

Later, this decision was developed in Cartesio case. Cartesio was a limited partnership incorporated in Hungary that applied for transferring its operational headquarters to Italy. ${ }^{15}$ However, the Hungarian Court rejected the application based on the Hungarian law which did not allow companies to move their operational headquarters to another Member State while maintaining their status as a Hungarian company. Cartesio claimed that it constituted a restriction on the right of establishment.

It was assumed by Advocates General that Hungarian law follows the real seat doctrine, as it requires the place of registration to coincide with the place of operational administration. ${ }^{16}$ Accordingly, AG Maduro noted that the Hungarian company law restricts "the "export" of a Hungarian legal person to the territory of another Member State' and this falls within the remit of the freedom of establishment. ${ }^{17}$ AG Maduro argued that although Member States were entitled to create their national company laws in the light of incorporation or the real seat theories, 'freedom of establishment required a minimum degree of mutual recognition and coordination of these various systems of rules so that neither could be applied to its fullest extent'. ${ }^{18}$ However, the ECJ held that should a company break off the

\footnotetext{
${ }^{16}$ Case 210/06 Cartesio(n 15), Opinion of AG Maduro paras 2-4 cited in Carsten Gerner-Beuerle and Michael Schillig 'The mysteries of freedom of establishment after Cartesio' (2010) 59(2) International \& Comparative Law Quarterly pp.3 <https://www.westlaw.com/Document/I7F74F542750211 DFB4ADB856E6oF7BC7/View/FullText.html?transitionTyp $\mathrm{e}=$ Default $\&$ contextData $=(\mathrm{sc}$. Default $) \& \mathrm{VR}=3.0 \& \mathrm{RS}=\mathrm{cblt1}$. $>$ accessed 20 November 2019

${ }^{17} \mathrm{lbid}$ para.23

18 Ibid para. 30
} 
connecting factor, the right of establishment could not be invoked against the loss of its legal identity. ${ }^{19}$ It relied on the reasoning in Daily Mail and noted that company's entitlement to the freedom of establishment can only be determined by applicable national law $^{20}$ and a Member State has a power not to allow a company governed under its law to maintain its legal status if company intends to transfer its connecting factor to another Member State .21 Nevertheless, the ECJ complemented this statement by giving an example of a different situation in which this power is restricted. In particular, when a company intends to move to another Member State "with an attendant change as regards the national law applicable", Home State is prohibited to require the liquidation of the company based on its national law. ${ }^{22}$ It found that this type of actual conversion of the company would fall within the ambit of freedom of establishment to the extent that the law of Host State allows such conversion. ${ }^{23}$

The judgment made in Cartesiocase resulted in controversial discussions among legal scholars, as it subjected the transfer of company's real seat to international private law (incorporation or real seat theories) of Member States, which differs from each other and consequently, brings about various outcomes with regard to the right of establishment. According to Gerner-Beuerle and Schilling, the criteria employed by the ECJ to determine the remit of articles 49 and 54 of the TFEU cause "arbitrary

\footnotetext{
${ }^{19}$ Cartesio(n15) para. 110

${ }^{20}$ Ibid para. 108

${ }^{21}$ Ibid para. 110

${ }^{22}$ Ibid paras 110-112

${ }^{23}$ Ibid para 113

${ }^{24}$ Carsten Gerner-Beuerle and Michael Schillig 'The mysteries of freedom of establishment after Cartesio'

(2010) 59(2) International \& Comparative Law Quarterly
}

results and lack of intrinsic justification". ${ }^{24}$ They have made an analysis of the transfer of company's real seat or registered seat cases in the light of incorporation and real seat theories of Home and Host States. The results of this case-by-case analysis revealed that: a) If a company intends to transfer its real seat from incorporation theory Home State, dissolution is not required, but if it transfers from the real seat theory Home State, it is subject to dissolution; ${ }^{25}$ b) If a company wishes to transfer its registered seat only with the change of its applicable law, Home State is not entitled to restrict such conversion by dissolution requirement, but what matters is the law of Host State. If Host State follows the incorporation theory, it may require reincorporation of the company depending on its law, which does not infringe the Articles 49, 54. However, transfer of registered seat to the real seat theory State leads to a vague result. Since the issue of whether the transfer of seat and conversion without liquidation is allowed is an area addressed by substantive law, the applicable law is determined by private international law. The real seat theory State determines applicable law based on the location of company's real seat, which is the State of incorporation that releases company from dissolution by referring to the law of Host State. ${ }^{26}$ Thus, rules created by the ECJ result in "circular argument". ${ }^{27}$

Later, the situation of company's conversion into a legal form of another Member State was

pp.6<https://www.westlaw.com/Document/l7F74F54275 0211DFB4ADB856E60F7BC7/View/FullText.html?transitio nType $=$ Default $\&$ contextData $=($ sc. Default $) \& V R=3.0 \& R S=c$ blt1. > accessed 20 November 2019

${ }^{25}$ Ibid pp.7

${ }^{26}$ Ibid pp. 8

${ }^{27} \mathrm{Ibid}$ 
considered in Vale case $^{28}$, the judgment of which shifted the case law concerning the corporate mobility in favour of companies. Vale CostruzioniSrl. (VS) was an Italian company, which applied to transfer its real seat as well as registered seat with an attendant change in its applicable law to Hungary as a legal successor of VS. Although this application was approved by Italian authorities, the Hungarian Court rejected to register the new Hungarian company VALE Építési as "the successor in law" ofltalain company VS based on its national company law which did not allow such conversion. Consequently, the Hungarian Supreme Court asked the ECJ for the preliminary ruling regarding the question whether this type of conversion falls within the ambit of freedom of establishment, if so, to what extent Hungarian company law can be applied in adjudicating on the application for registration. ${ }^{29}$ The ECJ held that Hungarian law was in breach of company's right of establishment. However, if the judgment in Cartesiowas followed, a different outcome could be expected. ${ }^{30}$ It was stated in an obiter dictum of the judgment ${ }^{31}$ that conversion with an attendant change was subject to the legislation of Host State where the company was supposed to re-incorporate. 32 Nevertheless, the Court inferred from the hypothetical case in Cartesio, which authorized companies for cross-border conversions within the ambit of the freedom of establishment ${ }^{33}$ and refined its judgment by imposing non-

\footnotetext{
${ }^{28}$ Case C-378/10 VALE Építésikft [2012] CMLR 41

29 Khan (n3) pp.4

30 Justin Borg-Barthet 'Free at Last? Choice of Corporate Law in the EU Following the judgement in Vale' (2013) 62

(2) The International and Comparative Law Quarterly, pp.507

<http://dx.doi.org/10.1017/S002058931300002X>accessed 20 November 2019

${ }^{31}$ Cartesio (n 15)
}

discrimination requirement on Host States and concluded that 'national legislation which enables national companies to convert, but does not allow companies governed by the law of another Member State to do so, falls within the scope of Articles 49 TFEU and 54 TFEU.'34 Moreover, a company is obliged to comply with the conditions of incorporation under the law of Host State before acquiring its nationality. ${ }^{35}$ Thus, the judgment in Vale granted a greater freedom to companies to choose a company law under which they wish to operate.

\section{Cross-border Mergers}

The judgment in SEVIC Systems ${ }^{36}$ case added a new element to EU case law concerning the protection of cross-border mergers under the freedom of establishment. Security Vision Concept (SVC) was a company established in Luxemburg, which intended to merge into a German company, SEVIC Systems AG (SEVIC), by method of acquisition. German law required mergers to be registered in the commercial register at the relevant place of incorporation of both absorbing and absorbed company. Since only one of the companies was located in Germany, SEVIC sought to register it at its place of incorporation. However, local court rejected the application for registration based on German law on transformations, which was designed only for domestic mergers. SEVIC appealed to German High Court, which asked for preliminary ruling about the question

\footnotetext{
32 Borg-Barthet (n 30)

33VALE Építésikft (n28) para. 49

34 Ibid paras 32-33

$35 \mathrm{Ibid}$

36 Case C-411/03, Sevic Systems AG v Amtsgericht Neuwied [2005] ECR I-10805
} 
whether cross-border mergers can be considered as an "establishment" within the meaning of Articles 43,48 (TEC) and if so, does the lack of provisions of German law allowing cross-border mergers constitute a restriction on the freedom of establishment. ${ }^{37}$ As regards the right of establishment, the ECJ stated that 'the right of establishment covers all measures which permit or merely facilitate access to another Member State [...] by allowing the persons to participate in the economic life of the country effectively and under the same conditions as national operators' 38 and noted that since cross-border merger projects satisfy the needs for collaboration and consolidation between corporations incorporated in different Member State, they are important for effective operation of internal market and therefore, constitute a particular type of "establishment".39 With respect to German law, it found that when a merger with a foreign company participation is treated differently compared to that of domestic one, it constitutes a restriction on the right of establishment regardless of whether this treatment comes from the Member State of the acquiring company or the Member State of the acquired company. ${ }^{40}$ Thus, the freedom of establishment was supposed to cover both inward and outward mergers.

\footnotetext{
37 Case C-411/03 Sevic Systems AG v Amtsgericht Neuwied (n34) cited in Peter Behrens 'Case C-411/03, SEVIC systems $A G$, judgment of the grand chamber of the court of justice of 13 december 2005, 2005] ECR I-10805' Common Market Law Review (2006) 43 (6)

<https://search.proquest.com/docview/220294095?accou ntid=14116 $>$ accessed 22 November 2019

${ }^{38}$ Sevic Systems AG v Amtsgericht Neuwied (n36) para 18

39lbid para.19

${ }^{40}$ Ibid para. 31

${ }^{41}$ Case C-307/97 Compagnie de Saint-Gobain, Zweigniederlassung Deutschland v. Finanzamt Aachen-
}

\section{Freedom of Choice Concerning Legal Forms of Transnational Establishment}

The ECJ stressed the freedom to choose the most suitable organizational structure in the Saint-Gobain Case by confirming that companies can freely choose an appropriate legal form for their economic activities in another Member State under the freedom of establishment principle. ${ }^{41}$ Previously, the ECJ addressed the freedom of choice concerning legal forms of transnational establishments in the avoir fiscal judgement ${ }^{42}$. This case involved French tax law which provided shareholders of domestic companies (with a French subsidiary) with tax credits on distributed dividends while leaving foreign companies with French subsidiary subject to the full company tax. ${ }^{43}$ The Commission argued that tax provisions in question amounted to "an indirect restriction" on the choice of corporations relating to the form of establishment (branch or subsidiary). ${ }^{44}$ The ECJ held that this provision was a discriminatory treatment that violated the principles of the freedom of establishment. ${ }^{45}$

The freedom of establishment relating to choice of organizational structure was developed by the judgments of subsequent

Innenstadt, [1999] ECR I-6161, para. 43

${ }^{42}$ Case 270/83 Commission v. France, [ 1986] ECR 273 cited in Wolfgang Schon 'The free choice between the right to establish a branch and to set-up a subsidiary-a principle of European Business Law' (2001) 2 (2) European Business Organization Law Review <https://www.westlaw.com/Document//3F92DB20721A11E093D 2C583C139DB77/View/FullText.html?transitionType=Default\&co ntextData $=($ sc. Default) $\& V R=3.0 \& R S=c b l t 1.0>$ accessed 22 November 2019

43 lbid

${ }^{44}$ Ibid

${ }^{45} \mathrm{Ibid}$ 
cases. In Centroscase ${ }^{46}$, Centros Ltd was established by two Danish nationals under UK law, in order to take advantage of UK's company law and to avoid minimum capital requirement imposed by Danish law. It sought to conduct all its business operations in Denmark by setting up a branch there but registration of the branch was refused by Danish authorities based on the reasoning that it was an abuse of freedom of establishment and unlawful way of national law evasion. However, AG La Pergola highlighted the right of Centros Ltd to choose legal form of its establishment by setting a branch or a subsidiary and argued that since a subsidiary would be an independent entity separate from its parent company, it would be subject to national law (including minimum capital requirement) and therefore rejection of the registration amounted to a restriction on the freedom of choice concerning form of establishment. ${ }^{47}$ The ECJ held that since the incorporation of a company in a State 'whose rules of company law seem the least restrictive and to set up branches in other Member States' is considered to be inherent right in the TFEU, the action of Centros Ltd could not be an abuse of law. ${ }^{48}$ Although this judgment extended the scope of freedom of establishment, it severely restricted the competence of States over overseas corporations especially those following the real seat theory.

\section{Polybud Case : departure from previous cases?}

In Polybudcase ${ }^{49}$, a Polish company transferred its registered seat (with an attendant change in applicable law) to Luxemburg while not changing the location of its real seat, and asked Polish registry court to remove it from register, but Polish authorities refused such application and commenced liquidation procedures based on Polish law. Polybud claimed that it was restriction on its right of establishment. The court held that such transformation falls within the scope of the freedom of establishment by inferring from previous decisions in Centros and Cartesio. ${ }^{50}$ It noted that since in Centros, a company incorporated in one Member State was entitled to conduct its operations in another Member State, conversely, a company seeking to transfer its registered seat should also be entitled to do so. It also recalled the judgment in Centros, which prohibited a Home Member State from restricting a company to convert into a legal form of a Host State. ${ }^{51}$ Therefore, it found that a Home State should not be allowed to restrict the transfer of the registered seat by imposing liquidation. However, opponents of this decision claim that it departs from previous interpretations. ${ }^{52}$ Specifically, they argued that as defined in particular previous cases ${ }^{53}$, the objective of the freedom of establishment is to safeguard "an actual, genuine economic activity" in another Member State, which did not mean a freedom to set "letterbox companies" with no connecting factor at all with the territory of Host State. ${ }^{54}$

\footnotetext{
${ }^{50}$ Markovinovic and Bilic (n 5) pp. 103

${ }^{51}$ Ibid pp.104

${ }^{52}$ Ibid pp. 105

${ }^{53}$ VALE Építésikft(n 28) and Case C-213/89 The Queen v Secretary of State for Transport[1990] ECR I-02433

${ }^{54}$ Markovinovic and Bilic (n 5) pp. 105
} 


\section{CONCLUSION}

In conclusion, despite particular uncertainties and incoherencies of EU case law on the freedom of establishment and incorporation theories, it extended the scope of the freedom of establishment principle to a great extent, thereby enabling MNEs to realize various crossborder objectives. Firstly, it facilitates "shopping" for corporate law by authorizing MNEs to choose their place of incorporation and nationality; secondly, it provides protection for both inbound and outbound transnational mergers; and lastly, it entitles them to choose the most appropriate organizational structure for their cross-border establishments.

As regards, the transfer of a registered seat and real seat, there are still uncertainties for certain cases due to the application of international private law such as incorporation and real seat theories. For example, a company like in Polybud case could be rejected by the real seat theory Host State. Thus, these areas of EU case law could be resolved by future cases or a Uniform Community Law.

\section{REFERENCES}

Primary Sources

1. Consolidated Version of the Treaty on the Functioning of the European Union [2012] OJ C326/47

2. Case $270 / 83$ Commission v. France, [ 1986] ECR 273

3. Case $81 / 87$ Daily Mail and General Trust plc [1988] ECR 5483 para. 19

4. The Queen $v$ Secretary of State for Transport [1990] ECR I-02433
5. Case C-212/97 Centros Ltd v. ErhvervsogSelskabsstyrelsen, [1999] ECRI-1459

6. Case C-212/97 Centros Ltd v. ErhvervsogSelskabsstyrelsen, [1999] ECRI-1459, Opinion of AG La Pergola para. 16

7. Case C-307/97 Compagnie de SaintGobain, Zweigniederlassung Deutschland v. Finanzamt AachenInnenstadt, [1999] ECR I-6161

8. Case C-208/00 Uberseering [2002] ECR I-9919

9. Case C-411/03, Sevic Systems AG v Amtsgericht Neuwied [2005] ECR I10805

10. Case 210/06 CartesioOktatóésSzolgáltatóbt. [2008] ECR I-9641

11. Case 210/06 CartesioOktatóésSzolgáltatóbt. [2008] ECR 1-9641, Opinion of AG Maduro paras 2-4

12. Case C-378/10 VALE Építésikft [2012] CMLR 41

13. Case C-106/16 Polbud - Wykonawstwo sp. $z$ 0.o[2017] ECLI-351

\section{Secondary Sources}

1. Behrens P., 'Case C-411/03, SEVIC systems $A G$, judgment of the grand chamber of the court of justice of 13 december 2005, 2005] ECR I-10805' Common Market Law Review (2006) 43

<https://search.proquest.com/docview /220294095?accountid=14116 > accessed 22 November 2019

2. Borg-Barthet J., 'Free at Last? Choice of Corporate Law in the EU Following the judgement in Vale' (2013) 62 (2) The International and Comparative Law 
Quarterly, pp.507 <http://dx.doi.org/10.1017/S002058931 $300002 X>$ accessed 20 November 2019

3. Gerner-Beuerle C., and Schillig M., 'The mysteries of freedom of establishment after Cartesio' (2010) 59(2) International \& Comparative Law Quarterly pp.3 https://www.westlaw.com/Document/ I7F74F542750211DFB4ADB856E60F7BC 7/View/FullText.html?transitionType=D efault\&contextData=(sc.Default)\&VR= 3.0\&RS=cblt1. $>$ accessed 20 November 2019

4. Khan A.,'Corporate Mobility, Market Access and the Internal Market' (2015) 40 (3) European Law Review pp.2 <https://www.westlaw.com/Documen t/I2BB262D0102A11E5AD4AE24CFD3BB 17D/View/FullText.html?transitionType $=$ Default\&contextData=(sc.Default) $\& \mathrm{~V}$ $\mathrm{R}=3.0 \& \mathrm{RS}=\mathrm{cb} \mid \mathrm{t} 1.0>$ accessed $\quad 15$ November 2019

5. Markovinovic H., and Bilic A., 'The Tranfer of A Company Seat to a Different Member State in the Light of the Recent “POLBUD” Decision' (2018) 5 (2) Journal for International and European Law and Market Integrations pp.99 <http://dx.doi.org/10.22598/iele.2018.5. 2.3>accessed 15 November 2019

6. Mörsdorf O., 'The legal mobility of companies within the European Union through Cross-Border Conversion' (2012) 49 (2) Common Market Law Review

<https://search.proquest.com/docview |1016796424? accountid=14116 > accessed 22 November

7. Schon W., 'The free choice between the right to establish a branch and to set-up a subsidiary-a principle of European Business Law' (2001) 2 (2) European Business Organization Law Review

<https://www.westlaw.com/Documen t/I3F92DB20721A11E093D2C583C139DB 77/View/FullText.html?transitionType= Default\&contextData $=(s c$. Default) $\& V R$ $=3.0 \& R S=$ cblt1. $>\quad$ accessed 22 November 2019

8. Wouters J., 'Private International Law and Companies' Freedom of Establishment' European Business Organization Law Review (2001) 2 (1) pp. 132-135 <https://search.proquest.com/docview /38291987?accountid=14116 >accessed 18 November

9. Wymeersch E., 'The transfer of the company's seat in European Company Law' (2003) 40 (3) Common Market Law Review <https://search.proquest.com/docview | 220275400?accountid=14116> accessed 18 November 2019

10. SardorMamanazarov, "LEGAL ISSUES OF THE ROLE OF SUPERVISORY BOARD IN GOVERNANCE JOINT-STOCK COMPANIES", JournalNX - A Multidisciplinary Peer Reviewed Journal, ISAE-2020, ISSN : 2581-4230, Page No. 1100-1107

11. Akramov, Akmal. "ProspectivesOf Trust Management of Property In Uzbekistan." The American Journal of Political Science Law and Criminology 2.11 (2020): 143-150.

12. Mirzaraimov B. Effective Measures Of Preventing Due Process Paranoia In International Arbitration //The American Journal of Political Science 
Law and Criminology. - 2020. - T. 2. №. 11. - C. 72-80.

13. Narziev, Otabek, Securities Market Regulation Theories and Perspectives of their Improvement (May 29, 2020). Available athttpbs://ssrn.com/abstract=3622883

14. Sadievich, NarzievOtabek. "Securities Market Development in CIS Countries: Legislative and Regulatory Lessons from Kazakhstan, Russia, and Uzbekistan." PhD diss., 神戸大学, 2019

15. Kozikowski, Jecek, OtabekNarziev, Naoyuki Okano, Sakae Suzuki, and Jean-Isamu Taguchi. "The Final Report of the Joint Research (Special Issue on Institution Design for Conflict Resolution and Negotiation-Theory and Praxis-)." 名古屋大學法政論集 258 (2014): 289-320.

16. Rustambekovlslombek, "Some Aspects of Development of Private International Law in the CIS Countries" (2020) LeXonomica 12 (1) 35 